\title{
Eating Disorders Associated with the Personality Traits of Institutionalized Drug Users
}

\author{
Geovanny Genaro Reivan - Ortiz ${ }^{1 *}$ and Patricia Elizabeth Ortiz-Rodas ${ }^{2}$ \\ ${ }^{1}$ Research professor of the Clinical Psychology Degree. Catholic University of Cuenca, Ecuador \\ ${ }^{2}$ Research professor at the Faculty of Hospitality Sciences, Gastronomy Degree. University of Cuenca, Ecuador \\ *Corresponding author: Geovanny Genaro Reivan Ortiz, Research professor of the Clinical Psychology Degree. Catholic University of \\ Cuenca, Ecuador
}

\begin{abstract}
The objective of this research was to determine the relationship between Eating Disorder (Anorexia Nervosa, Bulimia Nervosa, Binge Eating Disorders) and the personality traits of institutionalized drug users. Methodologically, there was a cross-sectional nonexperimental design of descriptive correlational type, with a non-probabilistic sample of 60 interns aged between 18 and 60 years $(M=32.5, S D=9.6)$ from three rehabilitation centers in the city of Ecuador basin. Two scales were applied to the EAT-40 and the Millon III Test. The results show that there is no statistically significant relationship.
\end{abstract}

Keywords: Personality Traits; Eating disorders; Drug addicts

\section{Introduction}

The Eating Disorders (ED) form a group of mental disorders differentiated by a behavior altered before the food intake and/or the appearance of behaviors focused on maintaining weight. This alteration causes physical problems and psychosocial functioning. The TCAs are diseases that have as main characteristics an exaggerated care for self-image and body weight (Vargas, 2013). The alterations of main importance included in this group are Anorexia Nervosa (AN), Bulimia Nervosa (BN) including Binge Eating Disorder (BED, American Psychiatric Association, 2014). New trends in fashion and new standards in physical appearance and eating patterns are described as possible triggers for the increase in the frequency of such disorders [1]. In the order of the previous ideas according to the fifth edition of the Diagnostic Manual of Mental Disorders (DSM-5), considers Anorexia Nervosa as a disorder in which the person has an excessive fear of gaining weight and a distortion of their image bodily. Practicing different activities to lose weight, such as restrictive diets very judicious, purging behaviors (self-induced vomiting, abuse of laxatives, use of diuretics, etc. [2]. It has been determined that up to $30 \%$ of anorexic patients manifest obsessive personality traits; as we have seen, there are clinical similarities between obsessive personality and restrictive eating disorders [3]. Nervous Bulimia was described as a variant of AN in 1979 by Russell. This disorder has repeated episodes of binge eating (anxious, uncontrolled intake), in which a large amount of food is eaten in a short time, usually in secret, followed by inappropriate compensatory behaviors (self-induced vomiting, laxative abuse, use of diuretics, physical hyperactivity,) together with a false perception of shape and body weight (Vargas, 2013). Binge Eating Disorder is identified by a pattern of altered eating behavior, in which the individual suffering from it presents recurrent episodes of compulsive eating. In these episodes dietary intakes are committed that are, in quantity and appetite, higher than what regularly consumes any person in the same period of time, experienced a feeling of lack of control. Being able to ingest a large amount of calories, reaching in some cases up to 20,000 kca. It differs from BN because this alteration does not occur compensatory behaviors, such as vomiting or the abusive use of laxatives or diuretics [4]. According to [5], it refers to the following personality traits associated with eating disorders, among which stand out: perfectionism, obsessive-compulsive traits and impulsivity, search for sensations, Narcissism, Sociotropy-autonomy then pose the basic postulates of the same: Perfectionism is established by the tendency to institute and pursue unrealistically high standards, taking into account the presence of adverse consequences (such as concern for food, weight and constant hunger). Researchers have recognized the relationship between eating disorders and a series of obsessive-compulsive traits, including doubts, verification and the need for symmetry and accuracy [6]. Impulsivity is determined by the lack of foresight, as well as the lack of awareness of risks 
and consequences before acting (for example, sudden decision of binges and purges, without considering the associated dysphoria and physical risks), numerous studies have shown that, in general, individuals with BN show high degrees of impulsivity [7]. Narcissism reflects a pathological anxiety for physical appearance and presentation, the need for external approval of the environment in which it develops, increased interpersonal sensitivity and decreased self-esteem. It is typical of individuals with AN or BN than those with other psychiatric disorders (that is, anxiety, affective and adaptation disorders), thus indicating this pathology as a unique risk factor for eating disorders.

Sociotropy-autonomy refers to a personality style determined by the care that the individual has regarding acceptance and approval by the medium, while autonomy is a personality style aimed at independence, control and achievement. In conclusion, correlational research suggests that $\mathrm{AN}$ and $\mathrm{BN}$ are characterized by perfectionism, obsessive-compulsive, narcissism, sociotropy and autonomy, while impulsivity and the search for sensations are more typical of disorders characterized by binge eating [5]. In the characteristics of the population of institutionalized drug users, it should be mentioned that these people suffer from a latent addictive disease influenced by various factors such as: lack of identity, violence, social influence, low self-esteem, and obsessivecompulsive personality traits, impulsivity, search for sensations and these in turn prevail to other disorders such as anorexia nervosa, bulimia nervosa, binge eating disorder, which in this study is about analyzing the degree of relationship. Previously verified studies have argued that certain drugs such as alcohol, cocaine and tobacco are more commonly used by people with eating disorders. It is considered that some personality traits such as search for new sensations, depression or anxiety, low self-esteem, and especially impulsivity, are frequent factors among eating disorders, such as bulimia nervosa, and the use of psychoactive substances [8]. The sustenance to study personality in eating disorders is based on the observation of specific patterns, such as low tolerance to frustration, poor control of impulses, inflexibility and the need for control that added to internment in a rehabilitation center by addictions, unleashes any change in the patient's psyche [5]. The objectives of this work are to characterize the personality traits of institutionalized drug users. Specify the risk of eating disorder of institutionalized drug users and analyze the degree of relationship of personality traits with the risk of suffering an eating disorder (Anorexia nervosa, Bulimia nervosa, Binge Eating Disorder) of the study participants.

\section{Materials and Methods}

The present investigation obeys a cross-sectional nonexperimental design of descriptive correlational type. We worked with a non-probabilistic sample of selection by male internal volunteers of $\mathrm{n}=60$ between the ages of 18 and 60 from the centers ( $M=32.5, \mathrm{SD}=9.6$ ), of the centers: The BARCA (Specialized Center in Treatment of Addictions), CETVI (Therapeutic Community "Thirst for life") and CRATI (Rehabilitation Center for Addicted Adolescents and Comprehensive Treatment in Mental and Physical Health), all therapeutic addiction centers belonging to the city of
Cuenca, Ecuador. As for the inclusion criteria, the institutionalized users of the rehabilitation centers were considered. The exclusion criteria were determined for users with mental deficit, organic and ambulatory pathologies. To carry out this research we worked with the Millon Multiaxial Clinical Inventory (MCMI-III) (Millon, 1997) is a self-report scale with 175 items that evaluates 14 personality patterns, and 10 clinical syndromes. The items have two response options (true-false). Its reliability was computed internal consistency (Alpha) and values were obtained between .66 and .90 respectively. Food Attitude Test (EAT-40) (Garner \& Garfinkel, 1979). It includes 40 items with 6 response options. The Likert scale, which is rated from 0 to 3 points, aims to measure symptoms and behaviors characteristic of ACT. With an internal consistency Alpha = .94 in a total sample, and .79 in AN, BN and TA [9]. The process of data collection with the approval of the entities responsible for each center by means of an official letter for the development of the research. Patients and health personnel were socialized for the purposes of the research, followed by the delivery of informed consent. The data were processed using the statistical package Statistical Package for the Social Science version 24.0, which allowed the statistical analysis to be carried out, through the construction of graphs and descriptive tables and correlations.

\section{Results}

As a first point, personality traits of institutionalized drug users were determined, identifying that of the total population $21.7 \%$ have antisocial personality traits, $18.3 \%$ depressive traits, as well as $15.3 \%$ paranoid personality traits the percentages being higher. The narcissistic personality traits are presented in $10 \%$, in regard to the sadistic and masochistic features there is $8.3 \%$, followed by the schizoid, avoidant, compulsive and schizotypal traits with a percentage of $3.3 \%$ each. Subsequent to this, $5 \%$ have dependent personality traits, and $1.7 \%$ have borderline features (Table 1). According to objective two, it is determined that $58.3 \%$ of the study population does not present risk of anorexia nervosa, $3.3 \%$ possibly presents, while in $11.7 \%$ it presents risk (Table 2). It is evident that $43.3 \%$ present no risk of Bulimia, $1.7 \%$ possibly present while $8.3 \%$ present (Table 3 ). It is observed that $42.4 \%$ of the population does not present risk of AT, $1.7 \%$ possibly presents, while $8.5 \%$ presents risk of AT (Tables 4-6). According to the last proposed objective; the degree of relationship between personality traits with the risk of eating behavior was analyzed using Spearman's statistical correlation, due to this, the most relevant result was the traits of depression with risk of Binge Eating Disorder, Bulimia and Anorexia, a non-statistically significant correlation was found with a very low level of relationship tending to nullity, such is the case: Depressive-Burn r (57) =.09, ns; Depressive - Bulimia r (58) $=.04, \mathrm{~ns}$; Depressive-anorexia; $\mathrm{r}(58)=.02$, ns (Table 5). Following the study, it was determined that the correlation between the Antisocial Personality Traits with the risk of Binge Eating Disorder and Bulimia is not statistically significant at a very low level; while with anorexia there is a level of nullity, such is the case of: Antisocial - Burn r (57) = .21, ns; Antisocial- Bulimia r (58) =. 11, ns; and Antisocial- Anorexia $r(58)=.07$, ns (Table 6). Finally, the association between Paranoid personality traits with risk of Binge Eating Disorder, Bulimia and Anorexia has a very low statistically 
insignificant correlation, such as the Paranoid-Burn case $r(57)=-.22$, ns; Paranoid- Bulimia r (58) $=-.20$, ns; and Paranoid- Anorexia $r$ (58) $=, 17$, ns respectively (Table 7).

Table 1: Rasgos de personalidad de usuarios drogodependientes institucionalizados.

\begin{tabular}{|c|c|c|c|}
\hline \multirow{2}{*}{ Personality Type } & \multicolumn{2}{|c|}{ Percentage } & Absence of Pathology \\
\cline { 2 - 4 } & Frequency & Presence of Pathology & 96,7 \\
\hline Schizoid & 2 & 3,3 & 96,7 \\
\hline Avoidative & 2 & 18,3 & 81,7 \\
\hline Depressant & 11 & 5,0 & 95,0 \\
\hline Dependent & 3 & 0 & 100,0 \\
\hline Histrionic & 60 & 10,0 & 90,0 \\
\hline Narcissistic & 6 & 21,7 & 78,3 \\
\hline Antisocial & 13 & 8,3 & 91,7 \\
\hline Sadistic & 5 & 3,3 & 96,7 \\
\hline Compulsive & 2 & 10,0 & 90,0 \\
\hline Negativist & 6 & 8,3 & 91,7 \\
\hline Masochistic & 5 & 3,3 & 96,7 \\
\hline Schizotypal & 2 & 1,7 & 98,3 \\
\hline Bordelinde & 1 & 15,3 & 84,7 \\
\hline Paranoid & 9 & & \\
\hline
\end{tabular}

Table 2: Risk of suffering an Eating Disorder in institutionalized drug users.

\begin{tabular}{|l|c|c|c|}
\hline \multirow{4}{*}{ Valid Percentages } & & Frequency & Percentage \\
\hline & Does not present & 35 & 58,3 \\
\cline { 2 - 4 } & Possibly does not present & 6 & 10,0 \\
\cline { 2 - 4 } & Zero risk & 10 & 16,7 \\
\cline { 2 - 4 } & Possibly presents & 2 & 3,3 \\
\cline { 2 - 4 } & Presents & 7 & 11,7 \\
\cline { 2 - 4 } & Total & 60 & 100,0 \\
\hline
\end{tabular}

Table 3: Bulimia risk of institutionalized drug users.

\begin{tabular}{|l|c|c|c|}
\hline \multirow{4}{*}{ Valid Percentages } & Frequency & Percentage & Percentage \\
\hline & Does not present & 26 & 43,3 \\
\cline { 2 - 4 } & Possibly does not present & 20 & 33,3 \\
\cline { 2 - 4 } & Zero risk & 8 & 13,3 \\
\cline { 2 - 4 } & Possibly presents & 1 & 1,7 \\
\cline { 2 - 4 } & Presents & 5 & 8,3 \\
\cline { 2 - 4 } & Total & 60 & 100,0 \\
\hline
\end{tabular}

Table 4: Bulimia risk of institutionalized drug users.

\begin{tabular}{|c|c|c|c|}
\hline & & Frequency & Percentage \\
\hline & Does not present & 25 & 41,7 \\
\hline Válido & Possibly does not present & 16 & 26,7 \\
\hline & Zero risk & 12 & 20,0 \\
\hline & Possibly presents & 1 & 1,7 \\
\hline & Presents & 5 & 9,3 \\
\hline & Total & 59 & 98,3 \\
\hline & System & 1 & 1,7 \\
\hline
\end{tabular}


Table 5: Bulimia risk of institutionalized drug users.

\begin{tabular}{|c|c|c|c|c|c|c|}
\hline & & & $\begin{array}{c}\text { Risk of binge } \\
\text { eating disorder }\end{array}$ & Risk Bulimia & Risk Anorexia & Depression \\
\hline \multirow{12}{*}{ Rho Spearman } & \multirow{3}{*}{$\begin{array}{l}\text { Risk of binge } \\
\text { eating disorder }\end{array}$} & $\begin{array}{c}\text { Correlation } \\
\text { coefficient }\end{array}$ & 1,000 &, $601^{* *}$ & ,092 &, 089 \\
\hline & & Sig. (bilateral) & . & ,000 & ,489 &, 502 \\
\hline & & $\mathrm{N}$ & 59 & 59 & 59 & 59 \\
\hline & \multirow{3}{*}{ Risk Bulimia } & $\begin{array}{c}\text { Correlation } \\
\text { coefficient }\end{array}$ &, $601^{* *}$ & 1,000 & ,233 &, 040 \\
\hline & & Sig. (bilateral) & ,000 & . & 073 & 763 \\
\hline & & $\mathrm{N}$ & 59 & 60 & 60 & 60 \\
\hline & \multirow{3}{*}{ Risk Anorexia } & $\begin{array}{c}\text { Correlation } \\
\text { coefficient }\end{array}$ & ,092 & ,233 & 1,000 &,- 021 \\
\hline & & Sig. (bilateral) & ,489 &, 073 & . & ,874 \\
\hline & & $\mathrm{N}$ & 59 & 60 & 60 & 60 \\
\hline & \multirow{3}{*}{ Depression } & $\begin{array}{c}\text { Correlation } \\
\text { coefficient }\end{array}$ & ,089 &, 040 &,- 021 & 1,000 \\
\hline & & Sig. (bilateral) &, 502 & ,763 & 874 & . \\
\hline & & $\mathrm{N}$ & 59 & 60 & 60 & 60 \\
\hline
\end{tabular}

Table 6: Antisocial personality correlation with TP, BN and AN of institutionalized drug users.

\begin{tabular}{|c|c|c|c|c|c|c|}
\hline & & & $\begin{array}{l}\text { Risk of Binge } \\
\text { Eating Disorder }\end{array}$ & Risk Bulimia & Risk Anorexia & Antisocial trait \\
\hline \multirow{12}{*}{ Rho Spearman } & \multirow{3}{*}{$\begin{array}{l}\text { Risk of Binge } \\
\text { Eating Disorder }\end{array}$} & $\begin{array}{l}\text { Correlation } \\
\text { coefficient }\end{array}$ & 1,000 &, $601^{* *}$ & ,092 & ,206 \\
\hline & & Sig. (bilateral) & . & ,000 & ,489 & 118 \\
\hline & & $\mathrm{N}$ & 59 & 59 & 59 & 59 \\
\hline & \multirow{3}{*}{ Risk Bulimia } & $\begin{array}{l}\text { Correlation } \\
\text { coefficient }\end{array}$ &, $601^{* *}$ & 1,000 & 233 & 106 \\
\hline & & Sig. (bilateral) & ,000 & . & ,073 & ,421 \\
\hline & & $\mathrm{N}$ & 59 & 60 & 60 & 60 \\
\hline & \multirow{3}{*}{ Risk Anorexia } & $\begin{array}{l}\text { Correlation } \\
\text { coefficient }\end{array}$ & ,092 & ,233 & 1,000 & ,072 \\
\hline & & Sig. (bilateral) & ,489 & 073 & . &, 584 \\
\hline & & $\mathrm{N}$ & 59 & 60 & 60 & 60 \\
\hline & \multirow{3}{*}{ Antisocial trait } & $\begin{array}{c}\text { Correlation } \\
\text { coefficient }\end{array}$ & ,206 & 106 & ,072 & 1,000 \\
\hline & & Sig. (bilateral) & 118 & ,421 &, 584 & . \\
\hline & & $\mathrm{N}$ & 59 & 60 & 60 & 60 \\
\hline
\end{tabular}

Table 7: Paranoid Personality Correlation with AN, BN and TP of institutionalized drug users.

\begin{tabular}{|c|c|c|c|c|c|c|}
\hline & & & $\begin{array}{l}\text { Risk of binge } \\
\text { eating disorder }\end{array}$ & Risk Bulimia & Risk Anorexia & Paranoid trait \\
\hline \multirow{6}{*}{ Rho Spearman } & \multirow{3}{*}{$\begin{array}{l}\text { Risk of binge } \\
\text { eating disorder }\end{array}$} & $\begin{array}{c}\text { Correlation } \\
\text { coefficient }\end{array}$ & 1,000 &, $601^{* *}$ & ,092 &,- 224 \\
\hline & & Sig. (bilateral) & . & ,000 & ,489 & ,088 \\
\hline & & $\mathrm{N}$ & 59 & 59 & 59 & 59 \\
\hline & \multirow{3}{*}{ Risk Bulimia } & $\begin{array}{l}\text { Correlation } \\
\text { coefficient }\end{array}$ &, $601^{* *}$ & 1,000 & ,233 &,- 204 \\
\hline & & Sig. (bilateral) & ,000 & . & 073 & ,118 \\
\hline & & $\mathrm{N}$ & 59 & 60 & 60 & 60 \\
\hline
\end{tabular}




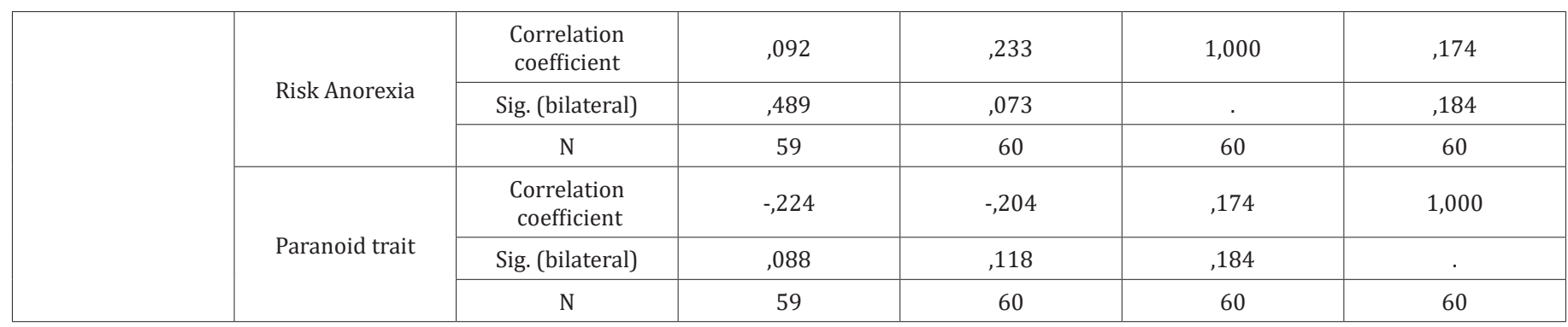

\section{Discussion}

According to the study carried out, it can be revealed that people with predominant features, both depressive, paranoid and antisocial, tend to develop or present in greater percentage problems of eating disorders such as anorexia nervosa, bulimia nervosa and binge eating disorders, however; [5], mention that AN and $\mathrm{BN}$ are characterized by the personality traits perfectionism, obsessive-compulsive, narcissism, sociotropy and autonomy, while impulsivity and the search for sensations are more typical of the disorders characterized by binge eating, which shows no similarity to the results of this investigation; it is possible to recover that in this study population there is the incidence of a pathology such as drug dependence, which can be considered as favorable for an ACT. Following this line Bear (2004), refers that the use of drugs can cause attempts to control the appetite, or in turn represent severe weight loss or bulimic behaviors associated with intoxication or deprivation. Likewise, it can be evidenced that there is a possible connection between anorexia or bulimia with antisocial personality disorder, drug dependence disorder, alcohol and major depressive disorder, these being the most punctuated personality traits in the study population. In addition to the above, it is specified that institutionalized users are in a process of rehabilitation, going through a withdrawal syndrome which could be considered as a triggering factor of an eating disorder, for example a cocaine consumer has loss of appetite tending to minimize or control weight; A consumer of cannabis tends to increase his appetite by relating to $\mathrm{BN}$ and $\mathrm{TP}$, with the aim of relieving anxiety and regulating emotions. As mentioned by [7], the most commonly consumed drugs are cocaine, amphetamines, cannabis and alcohol, influencing the appetite, and at the same time residing in the facilitation for the regulation of emotions. Based on the objectives set out in this research it is concluded that the study population there are $21.7 \%$ who present antisocial personality traits, $18.3 \%$ depressive traits, and $15.3 \%$ paranoid personality traits.

\section{Conclusion}

According to research conducted and what has been observed in different rehabilitation centers these features are considered more linked to an addiction. As a measure of foreseeing this event that brings about a family, social, mental and economic deterioration, an integral evaluation is necessary, to later have a solid base and foundation on the approaches of disease prevention and health promotion proposed by the World Organization of Health (1986). With this in the field of intervention of the clinical psychologist highlights the psychotherapeutic approach, guidance and prevention of relapses that will reinforce a physical and psychological recovery, highlighting the enhancement of a holistic care.

\section{References}

1. Baldares MJV (2013) Trastornos de la conducta alimentaria. Revista Médica de Costa Rica y Centroamérica (607): 475-482.

2. Marín B Verónica (2002) Trastornos de la conducta alimentaria en escolares y adolescentes. Revista chilena de nutrición 29(2): 86-91.

3. González L, Unikel C, Cruz C, Caballero A (2003) Personalidad y trastornos de la conducta alimentaria. Salud mental 26(3).

4. Baile José I (2014) Trastorno por atracón: Reconocido oficialmente como el nuevo trastorno del comportamiento alimentario. Revista médica de Chile 142(1): 128-129.

5. Stephanie E Cassin, Kristin M von Ranson T (2005) Personality and eating disorders: A decade in review. Clinical psychology review 25(7): 895-916.

6. Anderluh MB, Tchanturia K, Rabe Hesketh S, Treasure J (2003) Childhood obsessive-compulsive personality traits in adult women with eating disorders: Defining a broader eating disorder phenotype. American Journal of Psychiatry 160(2): 242-247.

7. Persano HL, Ventura AD, Gutnisky DA, Kremer CD, Mental S (2008) Consumo problemático de sustancias y desórdenes del comportamiento alimentario.

8. Calero Elvira A, Krug I, Davis K, López C, Fernández Aranda F, et al. (2009) Meta-análisis de drogas en personas con trastornos de la alimentación. Revisión de los trastornos de la alimentación en Europa: The Professional Journal of the Eating Disorders Association 17(4): 243259.

9. Behar R (2010) Revista Mexicana de Trastornos Alimentarios Mexican Journal of Eating Disorders. Revista Mexicana de Trastornos Alimentarios/Mexican Journal of Eating Disorders 1:132-138.

10. DSM-5: Manual Diagnóstico Y Estadístico De Los Trastornos Mentales. 5 a (edn.), American Psychiatric Association, USA.

11. Andrade Rodríguez, KA, Vera Duchi, MP (2016) Correlación entre tipos de personalidad en mujeres dependientes a sustancias en la ciudad de Cuenca-Ecuador 2015-2016 (Bachelor's thesis, Universidad del Azuay).

12. Behar Rosa (2004) Consumo de alcohol y trastornos de la conducta alimentaria: Evidencia, similitudes e implicancias. Revista chilena de neuro-psiquiatría 42(3): 183-194.

13. Cortez C, Yahoska H, Sánchez Martínez, AG (2016) Rasgos de la personalidad y su incidencia en el consumo de sustancias psicoactivas en los jóvenes internos en el "Hogar de Rehabilitación del Adicto" (HODERA) en el municipio de San Marcos, departamento de Carazo, durante el II semestre del 2016 (Doctoral dissertation, Universidad Nacional Autónoma de Nicaragua, Managua).

14. Galarsi M, Ledezma C, De Bortoli M, Correche M (2009) Rasgos de personalidad y trastornos de la conducta alimentaria en estudiantes universitarias. Fundamentos en Humanidades X(1): 157-166.

15. García Palacios A, Rivero I, Botella C (2004) Personalidad y trastornos de la conducta alimentaria. Comparación entre una muestra control y una 
muestra desde un enfoque categorial y dimensional. Revista Argentina de Clínica Psicológica.

16. Giraldo Osorio A, Toro Rosero MY, Macías Ladino AM, Valencia Garcés CA Palacio Rodríguez S (2010) La promoción de la salud como estrategia para el fomento de estilos de vida saludables. Revista hacia la Promoción de la Salud 15(1): 128-143.

17. Millon T, Millon C, Davis R, Grossman S (2009) MCMI-III: Millon Clinical Multiaxial Inventory. Pearson.

18. Ottawa C (1986) Promoción de la salud. In: Elaborada en la Primera Conferencia Internacional sobre la Promoción de la Salud, USA.
19. Rodríguez R, Marisol G (2017) Los rasgos de personalidad y su influencia en los trastornos de la conducta alimentaria en los/las adolescentes de Bachillerato de 16 a 17 años del Colegio de Bachillerato Beatriz Cueva de Ayora (Bachelor's thesis).

20. Veloso Gouveia V, Lucena Pronk S, Santos W, Gouveia R, Cavalcanti J (2010) Test de Actitudes Alimentarias: Evidencias de Validez de una Nueva Versión Reducida. Interamerican Journal of Psychology, 44 (1): 28-36

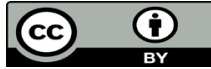

This work is licensed under Creative Commons Attribution 4.0 License

To Submit Your Article Click Here:

Submit Article

DOI: $10.32474 /$ LOJNHC.2019.02.000140

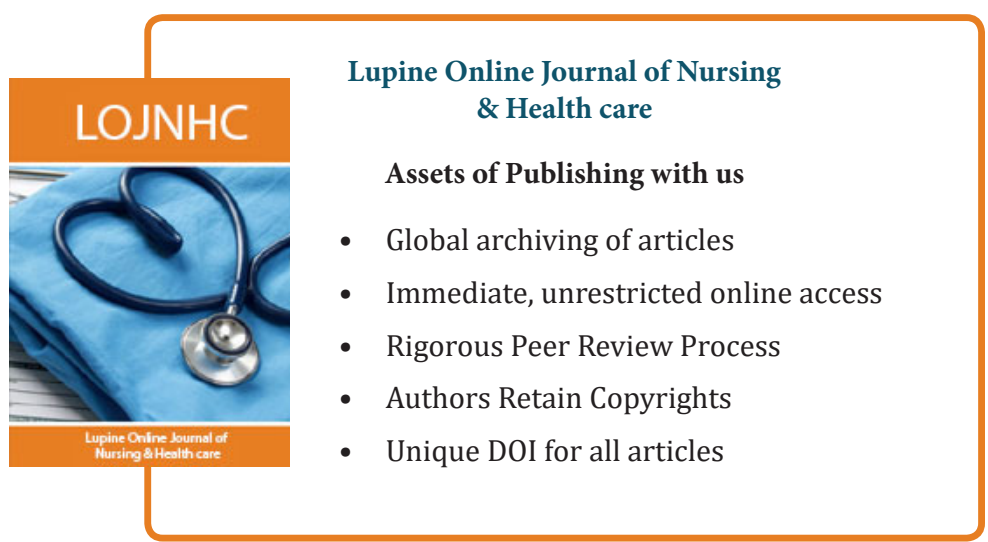

